Sains Malaysiana 49(1)(2020): 103-112

http://dx.doi.org/10.17576/jsm-2020-4901-12

\title{
Effect of Purified Soluble Polysaccharides Extracted from Gray Oyster Mushroom [Pleurotus sajor-caju (Fr.) Sing.] on 3t3-L1 Adipocytes
}

(Kesan Polisakarida Terlarut Tulen Diekstrak daripada Cendawan Tiram [Pleurotus sajor-caju (Fr.) Sing.] pada Adiposit 3t3-L1)

\author{
Decha Sermwittayawong*, Kulwanit Patninan, Chanawee Jakkawanpitak, Somruthai \\ Phothiphiphit, Siwarutt Boonyarattanakalin, Masashi Inafuku, Hirosuke OKu, \\ Kusumarn NoIPHa, \& NongPorn HutadiloK-Towatana
}

ABSTRACT

Functional mushroom polysaccharides have been known to the Asian traditional medicine for many years. The antiobesity activity of mushroom polysaccharides has been illustrated both in vivo and in vitro. However, the effect of pure polysaccharides on isolated fat cells has not been demonstrated. In this study, we used hot water and ammonium oxalate to extract polysaccharides from gray oyster mushroom [Pleurotus sajor-caju (Fr.) Sing.] and subsequently purified with enzymatic digestion, solvent extraction and ion-exchange chromatography. One of the fractions, 7S1-1, has the highest yield and purity and contains polysaccharides with the molecular weight around $500 \mathrm{kDa}$. In addition, Fourier transformed infrared spectroscopy (FTIR) and monosaccharide composition analyses showed that this 7S1-1 sample contains mostly B-glucan and some mannan. We find that the 7S1-1 fraction does not affect the total amount of triglycerides in the 3T3-L1 adipocytes but promotes a release of glycerol of the fat cells, suggesting that the fraction does not inhibit adipogenesis but stimulates lipolysis. Laminarin, a small $\beta$-glucan, confers similar results to the 7S1-1 sample, but it could not stimulate lipolysis as well as the 7S1-1 sample. Therefore, these results suggest a potential antiobesity activity of the mushroom polysaccharides.

Keywords: Anti-obesity; lipolysis; Pleurotus sajor-caju; polysaccharides; 3T3-L1 adipocytes

\section{ABSTRAK}

Cendawan fungsian polisakarida telah digunakan dalam perubatan tradisi di Asia selama bertahun-tahun. Aktiviti antiobesiti cendawan polisakarida telah ditunjukkan secara in vivo dan in vitro. Walau bagaimanapun, kesan polisakarida tulen pada pencilan sel lemak belum pernah ditunjukkan. Dalam kajian ini, kami menggunakan air panas dan ammonium oksalat untuk mengekstrak polisakarida daripada cendawan tiram [Pleurotus sajor-caju (Fr.) Sing.] dan kemudiannya ditulenkan dengan penghadaman enzim, pengekstrakan pelarut dan kromatografi pertukaran ion. Salah satu daripada pecahan, 7S1-1, mempunyai hasil dan penulenan tertinggi serta mengandungi polisakarida dengan berat molekul sekitar 500 kDa. Di samping itu, Spektroskopi transformasi Fourier inframerah (FTIR) dan analisis monosakarida menunjukkan bahawa sampel 7S1-1 ini mengandungi $\beta$-glukan kebanyakannya dan sedikit mannan. Kami mendapati bahawa pecahan 7S1-1 tidak memberi kesan kepada jumlah trigliserida dalam adiposit 3T3-L1 tetapi menggalakkan pembebasan gliserol daripada sel lemak, justeru mencadangkan bahawa pecahan tidak menghalang adipogenesis tetapi merangsang lipolisis. Laminarin, $\beta$-glukan kecil menghasilkan keputusan yang sama kepada sampel 7S1-1, tetapi ia tidak boleh merangsang lipolisis sebaik sampel 7S1-1. Oleh itu, keputusan ini mencadangkan aktiviti anti-obesiti yang berpotensi daripada cendawan polisakarida.

Kata kunci: Adiposit 3T3-L1; anti-obesiti; lipolisis; Pleurotus sajor-caju; polisakarida

\section{INTRODUCTION}

Mushroom polysaccharides have been shown to possess many biological activities such as immunomodulatory, antitumor, antiviral, wound healing, and antiobesity activities (Chen \& Seviour 2007). Several edible mushrooms such as linzhi (Garnoderma lucidum), Jew's ear mushroom (Auricularia auricula-judae), white fungus (Tremella fuciformis Berk.) and gray oyster mushroom (Pleurotus sajor-caju) have been used for polysaccharide isolation.

Although the role of polysaccharides in the immune system has been well characterized, the non-immune effects of polysaccharides such as anti-diabetic and anti-obesity are just beginning to be understood. For the anti-diabetic effect, mushroom polysaccharides have been shown to lower expression of pro-inflammatory cytokines, ameliorate glucose intolerance, insulin resistance and oxidative stress in mice (Kanagasabapathy et al. 2012). In 
tissue culture, we have previously shown that both crude and purified polysaccharides isolated from the gray oyster mushroom stimulated glucose uptake in L6 myotubes (Jantaramanant et al. 2014; Sermwittayawong et al. 2018) including cellular glucose uptake. Although cumulative evidence in literature suggests a connection between $\beta$-glucan and reduction of blood glucose concentration, a mechanism of how $\beta$-glucan affects cellular glucose uptake has not been demonstrated. In this study, we analyzed the effect of $\beta$-glucan containing polysaccharide extract from mushrooms on glucose uptake by the L6 myotubes. We extracted crude polysaccharide from fruiting bodies of the grey oyster mushroom (Pleurotus sajor-caju). The mechanism of how mushroom polysaccharides stimulates glucose uptake in muscle cells is currently being investigated.

In addition to the anti-diabetic effect, the mushroom polysaccharides have been shown to promote the antiobesity in tissue culture and animal. For example, studies showed that polysaccharides extracted from Angelica sinensis, Plantago asiatica L., and Radix Hedysari were able to reduce the overall body weight as well as the total cholesterol (TC), triglyceride (TG) and low density lipoprotein (LDL) in animal models (Hu et al. 2014; Sun et al. 2014; Wang et al. 2015). In cell culture, polysaccharides seemed to promote different effects on lipid metabolism in the cellular level, depending on their concentrations. It was reported that crude polysaccharides from Catathelasma ventricosum promoted lipogenesis in 3T3-L1 preadipocytes only at a low concentration, but conferred the inhibitory effect at a high concentration (Wang et al. 2012). Consistently, another study also showed that through AMP-activated protein kinase (AMPK) signaling, crude polysaccharides extracted from the gray oyster mushroom stimulated lipogenesis in the 3T3-L1 adipocyte at a low concentration, while induced lipolysis in the same cells at a high concentration (Kanagasabapathy et al. 2014). Together, crude polysaccharides may confer different effects to adipocytes, depending on their concentrations.

Although the effects of crude polysaccharides on 3T3L1 preadipocytes have been studied, it is not known whether purified polysaccharides would confer the same effects to the cells. In this study, the purified mushroom polysaccharide fraction, which contain less than $0.1 \%$ of total proteins and laminarin, a small algal $\beta$-glucan were investigated for their effects on both 3T3-L1 preadipocytes and differentiated adipocytes. The effect of 7S1-1, a mushroom polysaccharide fraction, was compared with laminarin. Here we show that the purified mushroom polysaccharide and laminarin do not affect adipogenesis, but promote lipolysis in differentiated adipocytes. These results illustrate a potential anti-obesity activity of pure polysaccharides and suggest the existence of specific receptor for polysaccharides on the surface of 3T3-L1 adipocytes.

\section{Materials And Methods}

\section{CELL CULTURE AND REAGENTS}

3T3-L1 preadipocyte (CL-173) from mouse (Mus musculus) were purchased from ATCC. Amylase, proteinase, proteinase $\mathrm{K}$ and glucose assay kit were purchased from Sigma-Aldrich. DEAE Sepharose fast flow was purchased from GE healthcare. Laminarin, insulin, dexamethasone, 3-isobutyl-1-methylxanthine (IBMX), and free-glycerol reagent were purchased from Sigma-Aldrich.

\section{PURIFICATION OF HOT WATER EXTRACTED POLYSACCHARIDES}

The hot-water extraction method and purification procedure are modified from our previous report (Sermwittayawong et al. 2018). Briefly, polysaccharides in the hot water extract were precipitated using five-volume of absolute ethanol. The subsequent procedures to eliminate proteins and unwanted polysaccharides were the same. Purification was performed only with DEAE ion-exchange column chromatography without going through gel-filtration column chromatography. The strategy of polysaccharide extraction and purification in this study is summarized in Figure 1.

\section{PURIFICATION OF AMMONIUM OXALATE EXTRACT POLYSACCHARIDES}

As described in Figure 1, the residue from hot water extraction was further extracted using ammonium oxalate as described previously (Sermwittayawong et al. 2018). Briefly, the residue was boiled with $1 \%$ ammonium oxalate at $98^{\circ} \mathrm{C}$ for $3-5 \mathrm{~h}$. The supernatant was collected following centrifugation and precipitated with ethanol. All subsequent steps for purification were performed as described above.

\section{TOTAL CARBOHYDRATES}

Total carbohydrates in the sample was analyzed using the phenol-sulfuric assay (Dubois et al. 1951), which was performed as previously described (Sermwittayawong et al. 2018).

\section{TOTAL PROTEINS}

Total amount of protein in the sample was determined using Bradford's assay (Bradford 1976), which was performed as previously described (Sermwittayawong et al. 2018).

\section{FOURIER TRANSFORMED INFRARED SPECTROSCOPY}

Fourier transformed infrared spectroscopy (FTIR) was performed by analyzing the mixture between a sample and KBr with Bruker Vertex 70 spectrometer (Bruker Optik, Germany). The spectra in the range of $400-4000 \mathrm{~cm}^{-1}$ were analyzed for functional groups. 


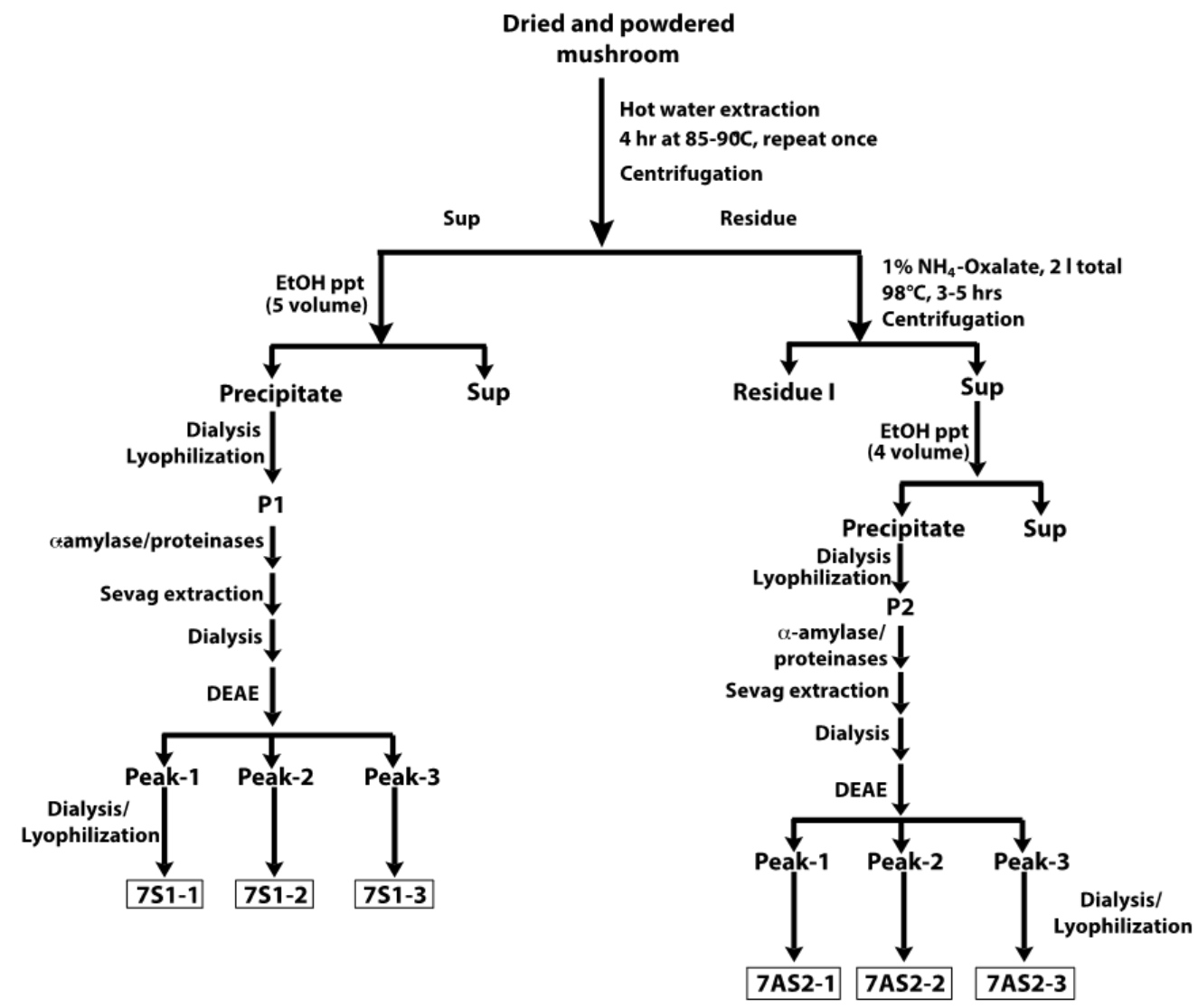

FIGURE 1. Schematic purification of polysaccharides from gray oyster mushroom

\section{MONOSACCHARIDE ANALYSIS}

The microwave radiation hydrolysis that was used to determine monosaccharide constituents of the 7S1-1 fraction was performed as described previously (Sermwittayawong et al. 2018).

\section{MOLECULAR WEIGHT DETERMINATION}

The molecular weight of 7S1-1 fraction was determined using size exclusion chromatography as previously described (Sermwittayawong et al. 2018).

\section{CELL VIABILITY ASSAY}

Cell viability assay was performed with 3(4,5-dimethylthiazol-2-yl)-5- (3-carboxymethoxyphenyl)2-(4-sulfophenyl)-2H-tetrazolium, inner salt (MTS), as recommended by the manufacturer's instruction (CellTiter ${ }^{\circledR}$ AQueous Non-Radioactive Cell Proliferation Assay, Promega Co., Madison, USA). Cell viability was reported as percent of relative viability against untreated control set.

\section{DIFFERENTIATION OF 3T3-L1 ADIPOCYTES}

3T3-L1 fibroblasts were grown in Dulbecco's Modified Eagle Medium (DMEM) supplemented with 10\% fetalbovine serum and $1 \%$ penicillin-streptomycin and incubated in a $37^{\circ} \mathrm{C}$ incubator with $5 \% \mathrm{CO}_{2}$. To differentiate, cells were seeded in a 24 -well plate until fully confluent. The medium was replenished and changed to D/A medium, which is the DMEM medium supplemented with $1 \mu \mathrm{M}$ dexamethasone, $0.5 \mathrm{mM} 3$-isobutyl-1methylxanthine (IBMX), and $10 \mu \mathrm{g} / \mathrm{mL}$ insulin and DMEM medium) after two days. Three days after incubation, the medium was changed to $\mathrm{D} / \mathrm{M}$, which is similar to $\mathrm{D} / \mathrm{A}$ except that IBMX and dexamethasone were omitted. This $\mathrm{D} / \mathrm{M}$ medium was replenished again after every two days of differentiation. The presence of lipid droplets under microscopic inspection suggests adipogenic differentiation.

\section{LIPID ACCUMULATION ASSAY}

In order to analyze the effect of polysaccharide on adipogenesis, sample at a desired concentration was added in D/A and D/M media throughout the course of differentiation. To determine the level of lipid accumulation, those cells were washed, fixed with formaldehyde, and stained with $0.3 \%$ Oil Red O (dissolved in $60 \%$ isopropanol), which binds to triglycerides and lipid. Stained cells were dissolved with $100 \%$ isopropanol and the absorbance was measured at $510 \mathrm{~nm}$.

\section{TRIGLYCERIDE (TG) ASSAY}

The procedures for isolation and purification of total triglycerides from the fat cells was modified from the previous literature (Folch et al. 1957). In brief, the fat cells 
were grown in a 48-well tissue culture plate and treated with polysaccharides as described before. After washing with phosphate saline buffer (PBS), 3T3-L1 adipocytes were extracted from the culture plate using $200 \mu \mathrm{L}$ of $1 \%$ Triton X-100 and subsequently transferred to a glass tube. Triglycerides in the cells were solubilized with $900 \mu \mathrm{L}$ of 4:5 methanol-chloroform mixture (v/v). After adding 250 $\mu \mathrm{L}$ of water, the content was vortexed and centrifuged. The resulting total triglycerides in the chloroform layer was transferred to a clean tube and dried using a speed vacuum concentrator. The triglycerides were subsequently resolubilized with $10 \%$ Triton X-100 in 2-propanol and quantified using a kit (Wako Pure Chemical Industries Ltd.) as recommended by the manufacturer's instruction.

\section{DOUBLE-STRANDED HIGH-SENSITIVITY ASSAY}

Cellular lysate with $1 \%$ Triton X-100 was used to measure their total DNA content with Quant-iT dsDNA HighSensitivity Assay kit (Molecular Probes) as recommended by the manufacturer's protocol.

\section{LIPOLYSIS ASSAY}

3T3-L1 differentiated adipocytes were treated with polysaccharide samples for $48 \mathrm{~h}$. If polysaccharides stimulate lipolysis, then the lipid inside the cells will be broken down into free fatty acids and glycerol and released into the medium. To detect free glycerol as evidence of lipolysis, medium from each treatment was assayed with Free Glycerol Reagent (Sigma-Aldrich). Product of the reaction is a quinoneimine dye, which shows a maximum absorbance at $540 \mathrm{~nm}$ wavelength.

\section{STATISTICAL ANALYSIS}

All experiments were performed at least 3 times independently and each data set was performed in a triplicate. Statistical analysis was determined using Student's T-Test (2-tailed, type-1).

\section{RESUlTS AND DiscUSSION}

\section{PURIFICATION AND CHARACTERIZATION OF POLYSACCHARIDE FRACTIONS}

Although we have previously reported extraction and purification of polysaccharides from the gray oyster mushroom (Sermwittayawong et al. 2018), the samples used in this study was from a different batch with modifications in extraction and purification procedures. First, in this study, the polysaccharides from hot water extract were precipitated using 4 volumes of ethanol rather than 1 volume reported in our previous publication. More ethanol added for precipitation of polysaccharides increases the yield. Second, we omitted the purification step using gel filtration, which is time-consuming and greatly reduces the yield. Without a purification step with gel filtration, a peak of polysaccharide eluted from the ion-exchange column is heterogenous in size. However, the total carbohydrate content of $7 \mathrm{~S} 1-1$ is very high $(94.36 \%)$, while the amount of protein contaminant is less than $0.1 \%$ (Table 1). Likewise, the 7AS2-1 fraction contains $98.41 \%$ of carbohydrates and less than $1 \%$ of protein contaminants. Therefore, we conclude that the 7S1-1 and 7AS2-1 samples are pure polysaccharides.

The 7S1-1 and 7AS2-1 fractions were selected for FTIR analysis. The results in Figure 2 shows the presence of the bandwidths at $1075-1067 \mathrm{~cm}^{-1}$ and $1044-1045 \mathrm{~cm}^{-1}$, which are indicatives for $\beta$-glucan (Galichet 2001). In addition, the bandwidths at $913-914 \mathrm{~cm}^{-1}$ represent mannan (Galichet 2001). These results suggest that these two polysaccharide fractions contain $\beta$-glucan and mannan.

Because of the lowest protein contaminants, we chose the 7S1-1 fraction for further analysis and for subsequent studies. The gel filtration analysis in Table 2 shows that 7S1-1 fraction consists of heterogeneous polysaccharides and the majority of the sample has the approximate size of $493 \mathrm{kDa}$. In addition, the monosaccharide analysis was performed and the identity of each peak was determined based on the standard monosaccharides. Glucose, galactose, arabinose, and mannose were used as standard monosaccharides, which have the retention time of 20.5, 24.5, 27.1, and $29.5 \mathrm{~min}$, respectively (data not shown). Despite the optimization, we could not completely digest polysaccharides into monosaccharides. Oligosaccharides, which has a retention time of less than $20 \mathrm{~min}$, became the major digested product (Table 2 and Figure 3 ). From Figure 3 , the peaks eluted with the retention time of 20 min onward are identified as glucose, mannose and arabinose. The data from Table 2 and Figure 3 together suggest that the 7S1-1 fraction mainly contains glucose, which makes up $\beta$-glucan detected in FTIR analysis. In addition, the data showed mannose, which comprises mannan found in Figure 2. Arabinose is another monosaccharide found in this analysis. However, the amount of mannose and arabinose in the sample combined is approximately 4.4 times lower than that of glucose (Table 2). Thus, we conclude that glucose is the major monosaccharide component, whereas mannose is the second most abundant monosaccharide found in the 7S1-1 sample.

\section{7s1-1 POLYSACCHARIDE SAMPLE DOES NOT AFFECT ADIPOGENESIS BUT ENHANCES LIPOLYSIS IN 3T3-L1 ADIPOCYTES}

In order to test the activity of the polysaccharide fraction with 3T3-L1 adipocyte, we first analyzed whether the polysaccharides were toxic to the cells. The effects of 7S11 polysaccharides and laminarin (small soluble $\beta$-glucan from Sigma-Aldrich) on viability of 3T3-L1 adipocytes are compared side by side. Results in Figure 4 show that both samples at all concentrations allow at least $80 \%$ viability in 3T3-L1 adipocytes, suggesting that polysaccharide samples are not toxic to adipocytes. 

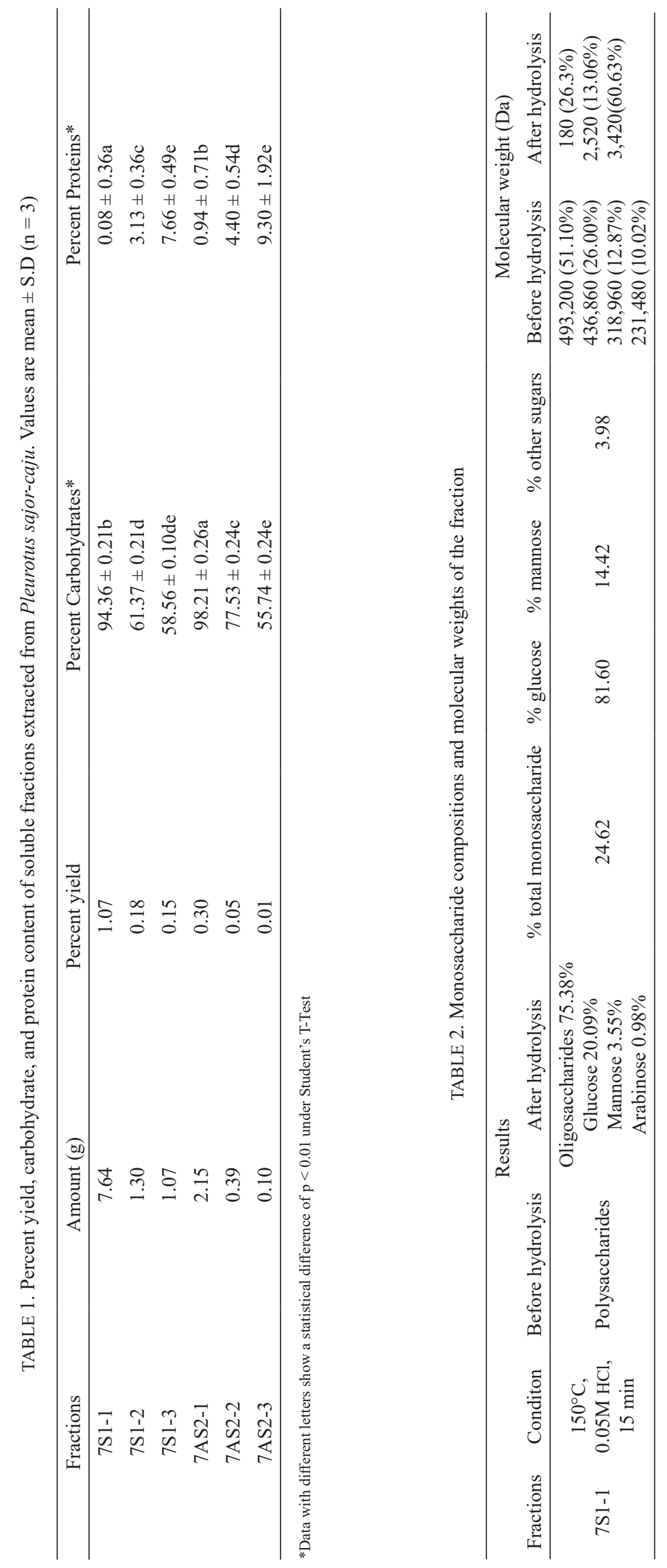
(A)

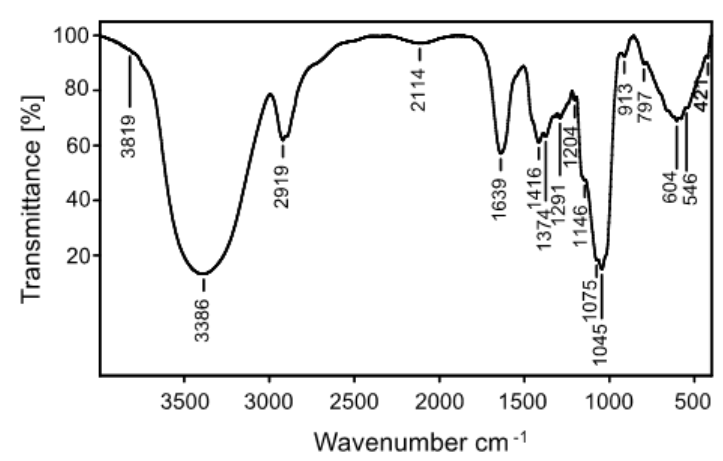

(B)

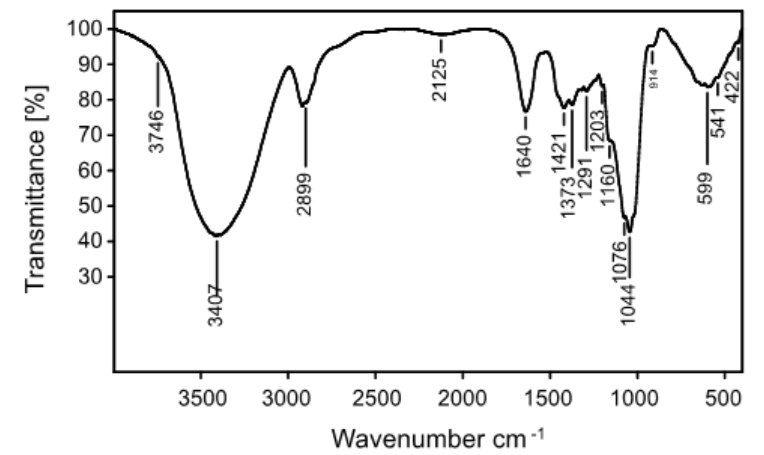

FIGURE 2. FTIR spectra of the polysaccharide samples. (A) FTIR spectra of 7S1-1 polysaccharide fraction. (B) FTIR spectra of 7AS2-1 polysaccharide fraction. The horizontal axis represents the wavenumber, which is inversely proportional to wavelength, whereas the vertical axis shows percent transmittance of the infrared spectra from $4000 \mathrm{~cm}^{-1}-400 \mathrm{~cm}^{-1}$

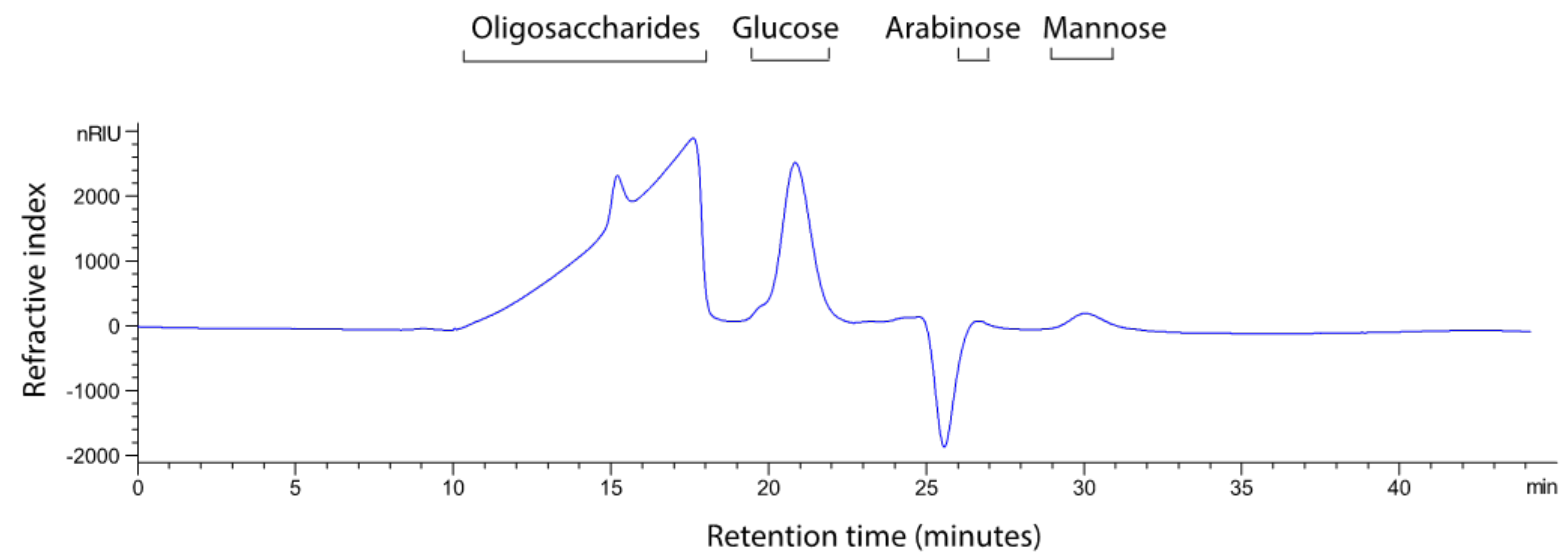

FIGURE 3. Glucose and mannose are the major monosaccharide constituents in the 7S1-1 polysaccharide fraction

To test the effect of polysaccharides on adipogenesis, differentiating adipocytes were incubated with the various concentrations of each polysaccharide sample, starting at the beginning of differentiation as described in materials and methods. If polysaccharides inhibit adipogenic differentiation, then less lipid accumulation through the Oil Red O staining assay would result. Data in Figure 5(A) shows that laminarin and 7S1-1 show only a marginal inhibition of lipid accumulation. In addition, the level of inhibition of lipid accumulation is not increased with the dose of polysaccharide samples. To further confirm the observation from the lipid accumulation assay, the triglyceride (TG) assay was also performed. Visnadine, which was previously shown to inhibit adipogenesis, was used as a positive control (Naoyuki et al. 2017). As shown in Figure 5(B), the increasing concentration of 7S1-1 does not reduce the amount of triglyceride content, while 25 $\mu \mathrm{M}$ visnadine inhibits triglyceride accumulation by approximately $50 \%$. Therefore, these results suggest that pure polysaccharides do not inhibit adipogenesis.

We further tested whether the purified 7S1-1 polysaccharide and laminarin would affect lipolysis in 3T3L1 adipocytes. To perform lipolysis, 3T3-L1 preadipocytes were completely differentiated into adipocytes prior to incubation with the polysaccharides. Lipolysis is a process that triglycerides are hydrolyzed into fatty acids and glycerol, which are released into the medium. The results show that treatment of 3T3-L1 adipocytes with laminarin causes a release of glycerol at the highest concentration, whereas treatment with 7S1-1 induces a release of glycerol in a dosedependent manner (Figure 6(A)). To further confirm this observation, we measured the amount of DNA in each sample (Figure 6(B)) and normalized the amount of glycerol released with the DNA content. The normalized data show that treatment with laminarin induces a significant release of glycerol at $4 \mathrm{mg} / \mathrm{mL}$, the highest concentration (Figure 6(C)). Noticeably, the 7S1-1 sample show a trend of lipolysis stimulation with a significant difference at $4 \mathrm{mg} / \mathrm{mL}$. Therefore, both laminarin and the 7S1-1 polysaccharides stimulate lipolysis in the fat cells, suggesting a potential anti-obesity effect of the polysaccharides.

The lipolysis stimulatory effect of polysaccharides has been illustrated. Kanagasabapathy et al. (2013) showed that oral administration of crude polysaccharides from the gray oyster mushroom reduced the weight of high-fat diet fed mice, perhaps by activating the expression of hormone 


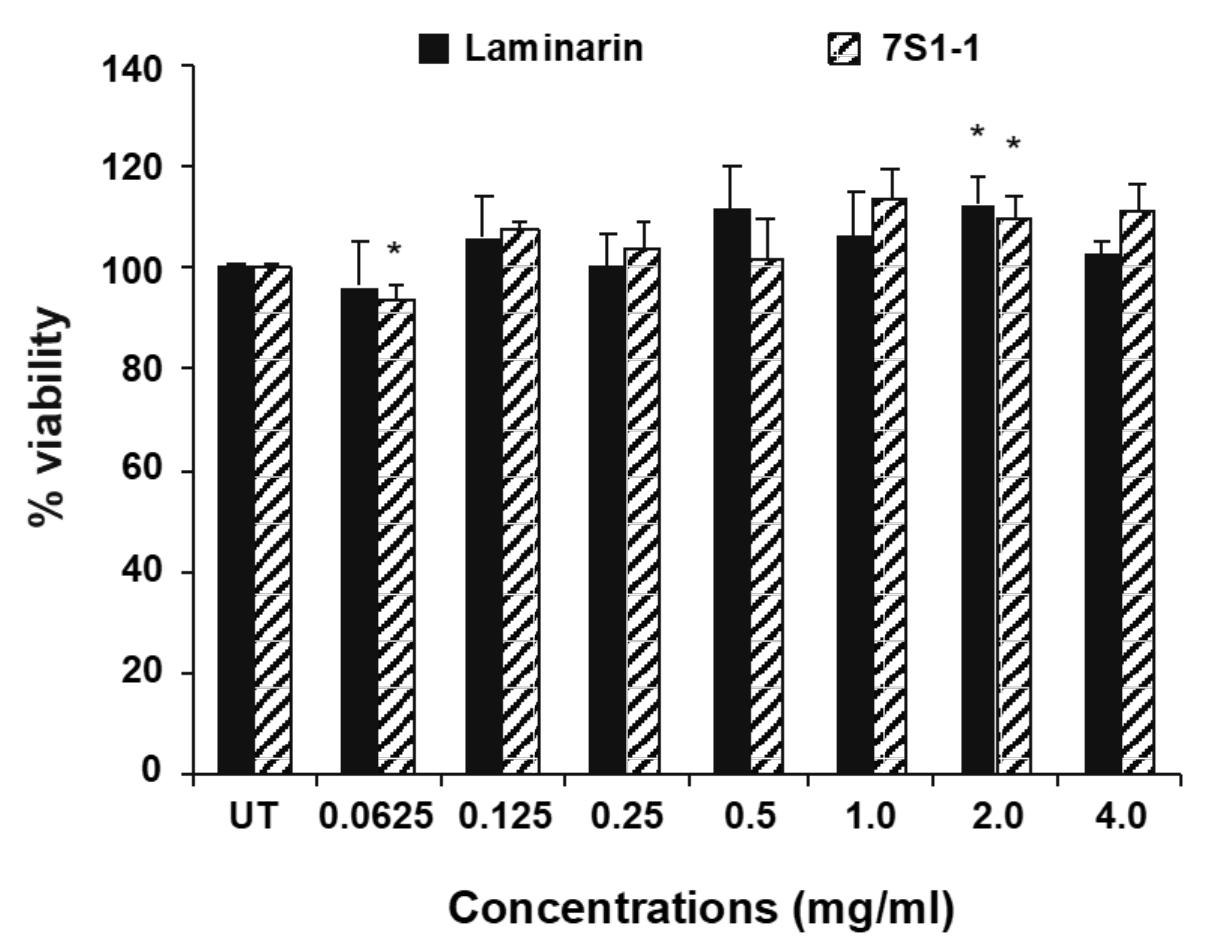

FIGURE 4. 7S1-1 polysaccharide fraction does not affect viability of differentiating 3T3-L1 preadipocytes. Each bar is the average of percent viability of differentiating 3T3-L1 preadipocytes treated with various concentrations of the 7S1-1 sample (0.0625-4 mg/ $\mathrm{mL}$ ) during the period of differentiation. UT is untreated control. The error bars represent standard deviations. Statistical differences compared with UT set were calculated using two-tailed Student's T-test $(*$ for $\mathrm{p}<0.05$ )

(A)

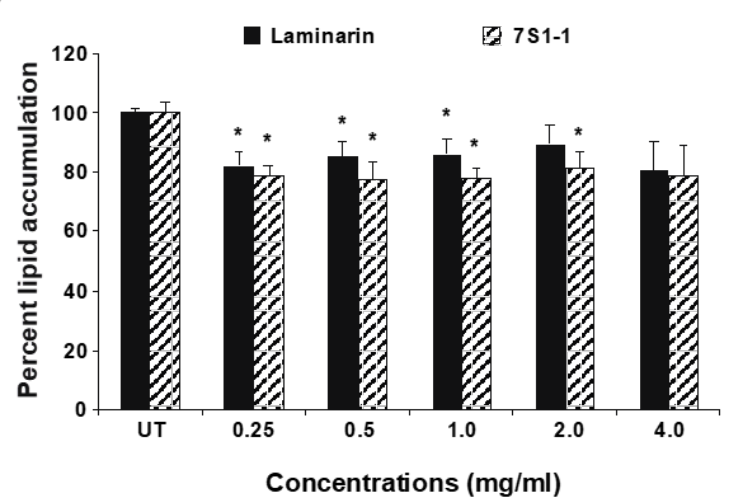

(B)

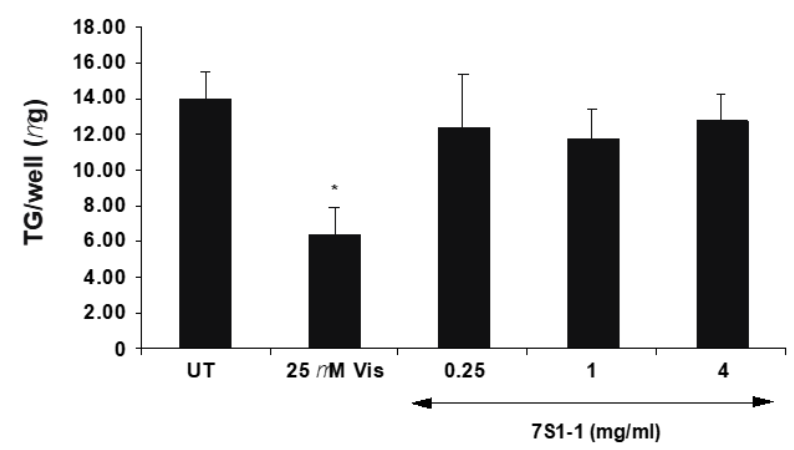

FIGURE 5. 7S1-1 polysaccharide fraction does not inhibit adipogenesis in differentiating 3T3-L1 preadipocytes. (A) Percent of lipid accumulation in 3T3-L1 adipocytes that were treated with different concentrations of polysaccharides throughout the course of differentiation. UT is abbreviated for untreated. (B) The amount of triglyceride (TG) in 3T3-L1 adipocytes treated cells. Visnadine (Vis) was used as a positive control for the TG assay. The error bars represent standard deviations. Statistical differences compared with UT set were calculated using two-tailed Student's T-test $(*$ for $\mathrm{p}<0.05)$

sensitive lipase $(H s l)$ and adipose triglyceride lipase $(\operatorname{Atgl})$, which are lipolysis stimulating genes. These results suggest the anti-obesity activity of crude polysaccharides. Consistently, many other studies also suggest the antiobesity activity of other polysaccharides (Hu et al. 2014; Sun et al. 2014; Wang et al. 2015).

The results in which $4 \mathrm{mg} / \mathrm{mL}$ mushroom polysaccharides confers a small effect on lipolysis of the fat cells suggest that soluble polysaccharides are not a good effector of 3T3-L1 adipocytes. This leads us to speculate that fungal pathogens, which contain polysaccharides on their cell wall, may elicit a better effect on adipocytes. Like the mushroom polysaccharides, laminarin stimulates lipolysis in the adipocytes as well, but the effect is much less pronounced. This is probably due to the fact that laminarin is approximately $5 \mathrm{kDa}$ in size, much smaller than the size of our mushroom polysaccharides.

The observation that polysaccharides from the gray oyster mushroom affect lipid accumulation in 3T3-L1 adipocytes has been demonstrated (Kanagasabapathy et al. 
(A)

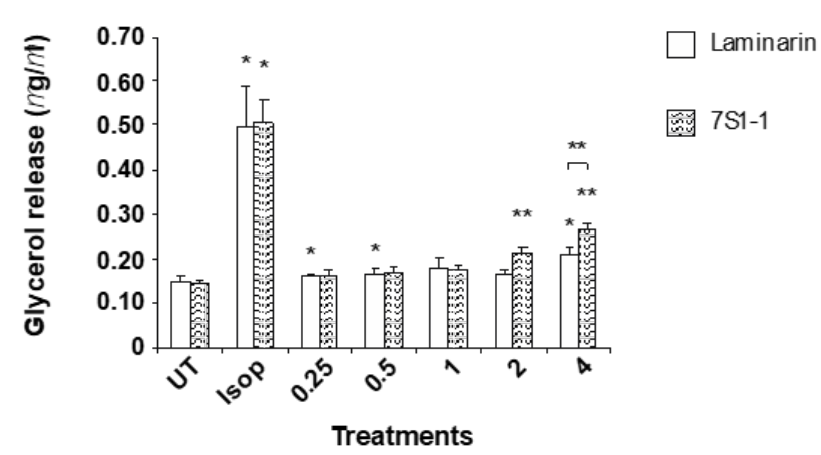

(B)

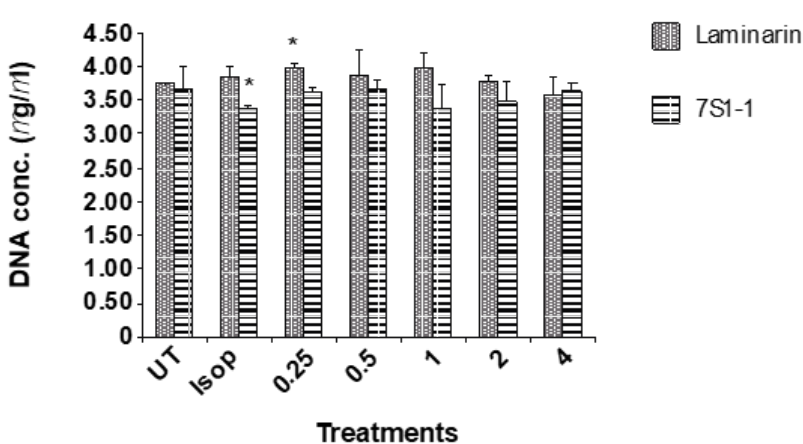

(C)

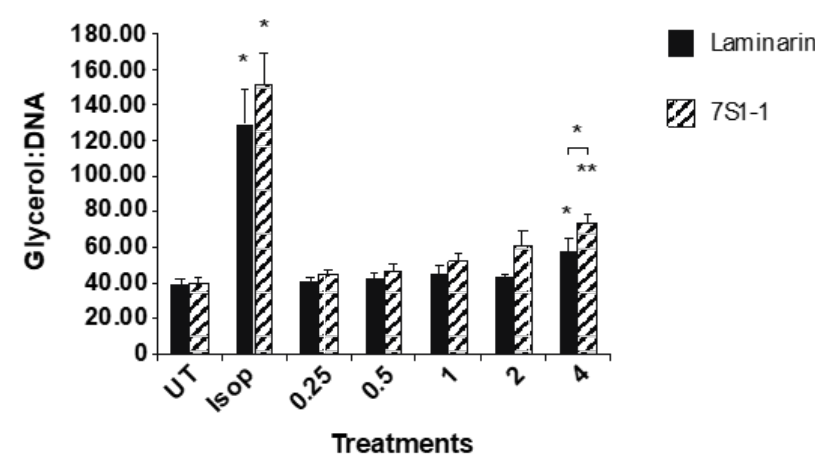

FIGURE 6. Polysaccharides enhance lipolysis. (A) measurement of glycerol released into the medium. (B) measurement of DNA content of 3T3-L1 adipocytes in each treatment. (C) the glycerol:DNA ratio of the adipocytes. Isop is abbreviated for isoproterenol $(100 \mathrm{nM})$, which is a positive control. Each bar is the average value. The error bars represent standard deviations. Statistical differences compared with UT set were calculated using two-tailed Student's T-test $(*$ for $\mathrm{p}<0.05$ and $* *$ for $\mathrm{p}<0.01$ )

2014). They found that the crude polysaccharides inhibited adipogenesis in a dose-dependent manner but stimulated lipolysis at the highest concentration. Although we cannot explain why our mushroom polysaccharides do not inhibit adipogenesis, the sample used in this study was pure polysaccharides and contains very little protein contaminant. Therefore, our results suggest that the lipolytic effect on 3T3-L1 adipocytes is conferred by the polysaccharides but not proteins.

Although the mechanism of how polysaccharides affect lipid metabolism has not been characterized, it would be interesting to test if our pure polysaccharides would signal through AMP-activated protein kinase (AMPK), as suggested by the previous study (Kanagasabapathy et al. 2014). In addition, the polysaccharides must be recognized by a specific receptor on the adipocytes. Therefore, the mechanism of how adipocytes response to polysaccharides will be elucidated in our future work.

\section{Conclusion}

Polysaccharides from the gray oyster mushroom was successfully extracted and purified. The analyses show that the highest yield fraction, namely $7 \mathrm{~S} 1-1$ is heterogeneous in size and mostly contain glucose and mannose. The FTIR analysis showed the presence of $\beta$-glucan and mannan in this sample. Interestingly, this 7S1-1 sample stimulates lipolysis but does not inhibit adipogenesis. Consistently, laminarin also confers similar results to the mushroom polysaccharide sample, even though the effect was less clear. These results suggest a 
potential anti-obesity activity of polysaccharide and a present of a receptor on the surface of 3T3-L1 adipocytes for a recognition of $\beta$-glucan.

\section{ACKNOWLEDGEMENTS}

We would like to thank Duang Dao Mushroom Farm at Banphru, Hat Yai, Songkhla for providing the gray oyster mushroom and Dr. Lim Seng Joe for reading the manuscript. DS would like to thank the Oku lab members for many helps and the Visiting Foreign Researcher Program for research training opportunity at the Center of Molecular Bioscience (COMB), the University of the Ryukyus. This work was supported by the Research Fund for the Development and Promotion of Science and Technology Talents (DPST) Graduate with First Placement (Grant\# 021/2557), and the Prince of Songkla University (Grant\# SCI600251S). The authors declare that they have no competing interests.

\section{REFERENCES}

Bradford, M.M. 1976. A rapid and sensitive method for the quantitation of microgram quantities of protein utilizing the principle of protein-dye binding. Analytical Biochemistry 72(1): 248-254. doi:https://doi.org/10.1016/00032697(76)90527-3.

Chen, J.Z. \& Seviour, R. 2007. Medicinal importance of fungal $\beta-(1 \rightarrow 3),(1 \rightarrow 6)$-glucans. Mycological Research 111(6): 635-652. doi:10.1016/j.mycres.2007.02.011.

Dubois, M., Gilles, K., Hamilton, J.K., Rebers, P.A. \& Smith, F. 1951. A colorimetric method for the determination of sugars. Nature 168(4265): 167.

Folch, J., Lees, M. \& Sloane, S.G.H. 1957. A simple method for the isolation and purification of total lipides from animal tissues. Journal of Biological Chemistry 226(1): 497-509.

Galichet, A. 2001. FTIR spectroscopic analysis of saccharomyces cerevisiae cell walls: Study of an anomalous strain exhibiting a pink-colored cell phenotype. FEMS Microbiology Letters 197(2): 179-186. doi:10.1016/S0378-1097(01)00101-X.

Hu, J.L., Nie, S.P., Wu, Q.M., Li, C., Fu, Z.H., Gong, J., Cui, S.W. \& Xie, M.Y. 2014. Polysaccharide from seeds of Plantago asiatica L. affects lipid metabolism and colon microbiota of mouse. J. Agric. Food Chem. 62(1): 229234. doi:10.1021/jf4040942.

Jantaramanant, P., Sermwittayawong, D., Noipha, K., HutadilokTowatana, N. \& Wititsuwannakul, R. 2014. B-glucancontaining polysaccharide extract from the grey oyster mushroom [Pleurotus sajor-caju (Fr.) Sing.] stimulates glucose uptake by the L6 myotubes. International Food Research Journal 21(2): 779-784.

Kanagasabapathy, G., Chua, K.H., Malek, S.N.A., Vikineswary, S. \& Kuppusamy, U.R. 2014. AMP-activated protein kinase mediates insulin-like and lipo-mobilising effects of $\beta$-glucan-rich polysaccharides isolated from Pleurotus sajor-caju (Fr.), singer mushroom, in 3T3L1 cells. Food Chemistry 145: 198-204. doi:10.1016/j. foodchem.2013.08.051.

Kanagasabapathy, G., Malek, S.N., Mahmood, A.A., Chua, K.H., Vikineswary, S. \& Kuppusamy, U.R. 2013. Beta- glucan-rich extract from Pleurotus sajor-caju (Fr.) singer prevents obesity and oxidative stress in $\mathrm{C} 57 \mathrm{BL} / 6 \mathrm{~J}$ mice fed on a high-fat diet. Evid. Based Complement. Alternat. Med. 2013: 185259. doi:10.1155/2013/185259.

Kanagasabapathy, G., Kuppusamy, U.R., Abd Malek, S.N., Abdulla, M.A., Chua, K.H. \& Sabaratnam, V. 2012. Glucanrich polysaccharides from Pleurotus sajor-caju (Fr.) singer prevents glucose intolerance, insulin resistance and inflammation in C57BL/6J mice fed a high-fat diet. $B M C$ Complement. Altern. Med. 12: 261. doi:10.1186/14726882-12-261.

Sermwittayawong, D., Patninan, K., Phothiphiphit, S., Boonyarattanakalin, S., Sermwittayawong, N. \& HutadilokTowatana, N. 2018. Purification, characterization, and biological activities of purified polysaccharides extracted from the gray oyster mushroom [Pleurotus sajor-caju (Fr.) Sing.]. Journal of Food Biochemistry 42(5): e12606. doi:10.1111/jfbc.12606.

Sun, W.M., Wang, Y.P., Duan, Y.Q., Shang, H.X. \& Cheng, W.D. 2014. Radix hedysari polysaccharide suppresses lipid metabolism dysfunction in a rat model of nonalcoholic fatty liver disease via adenosine monophosphateactivated protein kinase pathway activation. Mol. Med. Rep. 10(3): 1237-1244. doi:10.3892/mmr.2014.2327.

Naoyuki Taira, Ruwani N Nugara, Masashi Inafuku, Kensaku Takara, Takayuki Ogi, Toshio Ichiba, Hironori Iwasaki, Takafumi Okabe. \& Hirosuke Oku. 2017. In vivo and in vitro anti-obesity activities of dihydropyranocoumarins derivatives from Peucedanum japonicum Thunb. Journal of Functional Foods 29: 19-28. doi:https://doi.org/10.1016/j. jff.2016.11.030.

Wang, K.P., Cao, P., Shui, W.Z., Yang, Q.X., Tang, Z.H. \& Yu, Z. 2015. Angelica sinensis polysaccharide regulates glucose and lipid metabolism disorder in prediabetic and streptozotocin-induced diabetic mice through the elevation of glycogen levels and reduction of inflammatory factors. Food \& Function 6(3): 902-909. doi:10.1039/ C4FO00859F

Wang, X., Liu, H., Zhao, L., Dong, H., Wang, Y., Sun, D., Liu, Y., Yang, R. \& Li, X. 2012. Effects of crude polysaccharides from Catathelasma ventricosum on the proliferation and differentiation of 3T3-L1 cells. Agricultural Journal 7(3): 187-190.

Decha Sermwittayawong*, Kulwanit Patninan \& Chanawee Jakkawanpitak

Department of Biochemistry

Faculty of Science

Prince of Songkla University

Hat Yai, Songkhla 90110

Thailand

Somruthai Phothiphiphit \& Siwarutt Boonyarattanakalin

School of Bio-Chemical Engineering and Technology

Sirindhorn International Institute of Technology

Thammasat University

Pathum Thani 12121

Thailand

Masashi Inafuku \& Hirosuke Oku

Molecular Biotechnology Group 
Center of Molecular Biosciences Tropical Biosphere Research Center University of the Ryukyus

1 Senbaru, Nishihara

Okinawa 903-0213

Japan

Kusumarn Noipha

Faculty of Health and Sports Science

Thaksin University

Paphayom, Phatthalung, 93110

Thailand
Nongporn Hutadilok-Towatana

Krisana Kraisintu Foundation

13/217 Plum Condominiums Phaholyothin

Thailand

*Corresponding author; email: decha.s@psu.ac.th

Received: 24 May 2019

Accepted: 15 October 2019 